\title{
Travle allmennleger - oftere antibiotika
}

\section{Jo flere konsultasjoner per år, desto hyppigere forskriver all- mennleger antibiotika. Leger som skriver ut mest antibiotika, velger mer bredspektrede midler.}

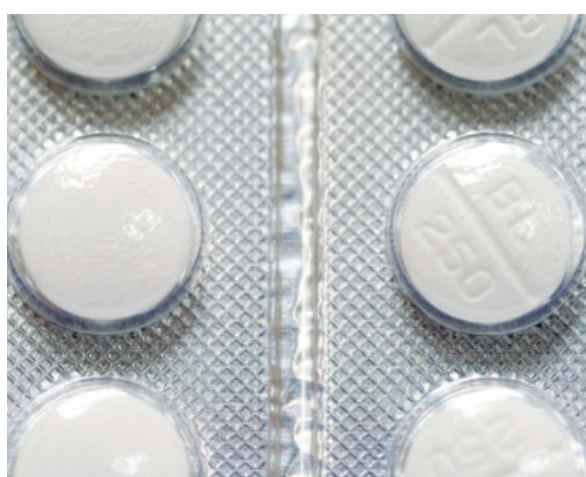

Illustrasjonsfoto Sciencephoto/SCANPIX
Dette viser resultatene fra vår studie om kollegabasert terapiveiledning (1). Undersøkelsen omhandler allmennlegers antibiotikaforskrivning for akutte luftveisinfeksjoner basert på resept- og diagnosedata fra 440 norske allmennleger gjennom ett år i 2004-05.

Legene behandlet totalt 142900 episoder med akutte luftveisinfeksjoner. I $33 \%$ av disse episodene skrev legen ut et antibiotikum, hvorav penicillin $\mathrm{V}$ ble valgt hos $41 \%$. Oddsratio for å skrive ut et antibiotikum var 1,6 ganger høyere blant de legene som hadde flest konsultasjoner per år i sin praksis (øvre femdel), sammenliknet med dem som hadde færrest konsultasjoner per år. Oddsratio for å velge et annet antibiotikum enn penicillin $\mathrm{V}$ var 2,8 ganger høyere hos høyforskrivere sammenliknet med hos lavforskrivere.

Studien viser at norske fastleger fortsatt har en relativt lav forskrivningsrate for antibiotika og høy andel av penicillin $\mathrm{V}$ ved antibiotikaforskrivning. Forskrivningsraten og andelen bredspektrede antibiotika bør og kan fortsatt reduseres.

\section{Svein Gjelstad}

svein.gjelstad@medisin.uio.no

Antibiotikasenteret for primærmedisin og

Allmennmedisinsk forskningsenhet

Universitetet i Oslo

Litteratur
1. Gjelstad S, Straand J, Dalen I et al. Do general practitioners' consultation rates influence their prescribing patterns of antibiotics for acute respiratory tract infections? J Antimicrob Chemother $2011 ; 66: 2425-33$

\section{Virkningsmekanisme for tuberkulostatikum kartlagt}

\section{Pyrazinamid hemmer den bakterielle mekanismen trans-translasjon, som er viktig for overlevelsen av Mycobacterium tuberculosis.}

Pyrazinamid brukt i kombinasjon med andre tuberkulostatika bidrar til kortere behandlingstid ved tuberkulose. Pyrazinamid omdannes til den aktive metabolitten pyrazinsyre av et mykobakterielt enzym, men den videre virkningsmekanisme er ikke klarlagt. Nå har en internasjonal forskergruppe studert molekylære effekter av pyrazinsyre i M tuberculosis (1).

Studien viser at pyrazinsyre virker ved å binde seg til et mykobakterielt ribosomalt protein, RpsA, et molekyl som er nødvendig for translasjon. RpsA bindes også til bakterielt tmRNA, et RNA-molekyl med egenskaper lik både tRNA og mRNA, som bidrar til frigjøring av blokkerte ribosomer som følge av f.eks. medikamenteksponering. Denne prosessen kalles trans-translasjon og er viktig for ikke-replikerende bakteriers overlevelse. Når pyrazinsyre binder RpsA, hindrer dette tmRNA-binding og dermed også trans-translasjon. Forskerne oppdaget at mutasjoner i bindesetet til pyrazinsyre på $r p s A$-genet hindrer pyrazinsyre $\mathrm{i}$ å binde seg, noe som gjør RpsA fritt til å binde tmRNA og dermed sørge for at bakterien overlever.
- Dette er svært interessante funn, sier Ruth Stavrum ved Gades institutt, Universitetet i Bergen. - Infeksjon med pyrazinamidresistente bakterier forlenger behandlingstiden fra seks til ni måneder, og pyrazinamid blir også ofte brukt $\mathrm{i}$ behandling av multiresistente $\mathrm{M}$ tuberculosis-stammer. Den lange behandlingstiden av tuberkulose resulterer ofte i at pasienter ikke fullfører. Dermed øker risikoen for at det utvikles ekstensivt resistente bakterier, såkalte XDR.

Antibiotikaresistens er et stort problem, og oppdagelsen av resistensskapende mutasjoner i rpsA-genet gir ny kunnskap om pyrazinsyrens virkemåte. Dette kan trolig utnyttes $i$ utviklingen av nye antituberkuløse legemidler, sier Stavrum.

\section{Trine B. Haugen}

trine.b.haugen@hf.hio.no

Tidsskriftet

\section{Litteratur}

1. Shi W, Zhang $X$, Jiang $X$ et al. Pyrazinamide inhibits trans-translation in Mycobacterium tuberculosis. Science 2011; 333: 1630-2.

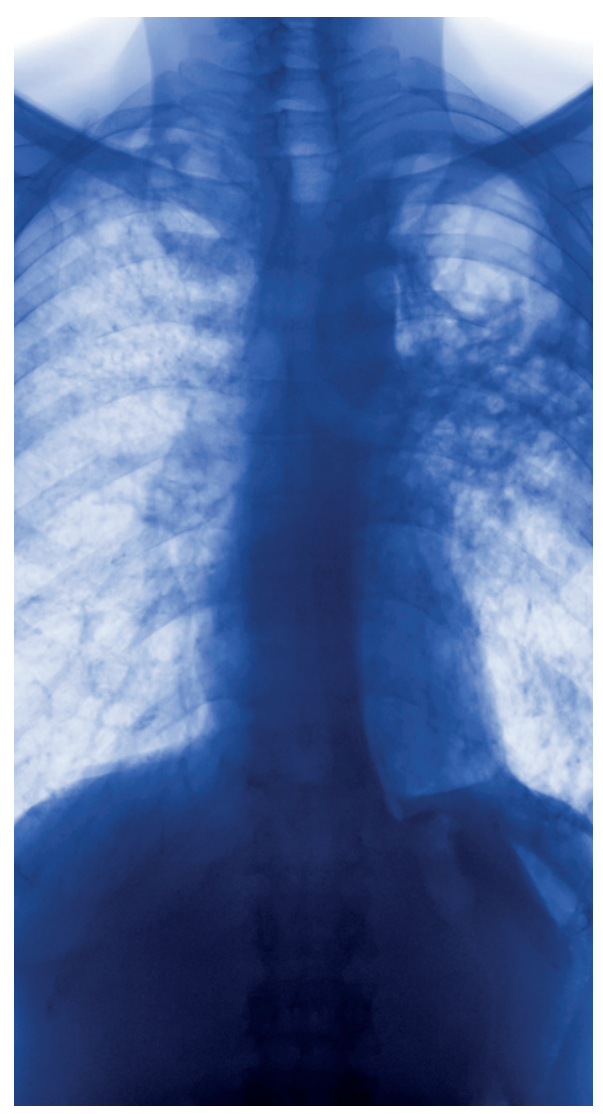

Illustrasjonsfoto Sciencephoto/SCANPIX 